\title{
Primum non nocere. Trudności związane z leczeniem przeciwkrzepliwym pacjentów w podeszłym wieku
}

\author{
Primum non nocere. Difficulties related to anticoagulation therapy \\ of elderly patients
}

\author{
Michał Narożny, Grzegorz Skonieczny
}

Oddział Kardiologii i Intensywnej Terapii Kardiologicznej Wojewódzkiego Szpitala Zespolonego im. Ludwika Rydygiera w Toruniu

\section{Streszczenie}

Pierwszym krokiem leczenia przeciwkrzepliwego jest podjęcie decyzji terapeutycznej opartej na bezwzględnym ryzyku zatorów i krwawień oraz na względnym stosunku korzyści do ryzyka u danego pacjenta. Przeanalizowano przypadek kliniczny pacjentki w podeszłym wieku, z licznymi obciążeniami oraz wysokim ryzykiem krwawienia, wymagającej terapii antykoagulantem.

Celem pracy było zwrócenie uwagi na zmienność ryzyka krwawienia w trakcie długoletniego leczenia. Na podstawie badań klinicznych oraz aktualnych wytycznych można uznać wyższość nowych doustnych leków przeciwkrzepliwych nad klasyczną terapią antagonistami witaminy $\mathrm{K}$.

Słowa kluczowe: leczenie przeciwkrzepliwe, antykoagulant, riwaroksaban, dabigatran, przedawkowanie, działania niepożądane

Folia Cardiologica 2017; 12, 1: 91-95

\section{Wstęp}

Doustne leczenie przeciwkrzepliwe dotyczy milionów pacjentów na całym świecie. Wskazania do stosowania antykoagulantów obejmują jednostki chorobowe powszechnie występujące, dlatego stało się ono codziennością w praktyce zarówno lekarzy podstawowej opieki zdrowotnej, jak i pracujących na oddziałach szpitalnych.

Populacja Europy starzeje się. Średnie przeżycie się wydłuża. Zmiany te powodują wzrost liczebności populacji powyżej 80. roku życia. To właśnie pacjenci w podeszłym wieku najczęściej wymagają terapii przeciwkrzepliwej, a tym samym szczególnej uwagi w starannym doborze odpowiedniego leku i troskliwej opieki w trakcie terapii. Również modyfikacja skali $\mathrm{CHADS}_{2}$ do $\mathrm{CHA}_{2} \mathrm{DS}_{2}$-VASc, poprzez dodanie do niej kolejnych czynników ryzyka zatorów, przyczyniła się do zwiększenia grona pacjentów kwalifikowanych do wdrożenia terapii przeciwkrzepliwej.
Doustne leczenie przeciwkrzepliwe stosuje się w zapobieganiu udarom i zatorowości obwodowej w migotaniu lub trzepotaniu przedsionków, profilaktyce i leczeniu żylnej choroby zakrzepowo-zatorowej (zakrzepica żył głębokich i zatorowość płucna) czy prewencji pierwotnej żylnych powikłań zatorowo-zakrzepowych po alloplastyce całkowitej stawu kolanowego lub biodrowego.

\section{Opis przypadku}

Pacjentka w wieku 74 lat, skarżąca się na ból głowy, pogorszenie tolerancji wysiłku oraz złe samopoczucie, została przekazana transportem medycznym z przychodni w miejscu zamieszkania na szpitalny oddział ratunkowy z powodu stwierdzonej ambulatoryjnie niedokrwistości oraz wysokich wartości międzynarodowego współczynnika znormalizowanego (INR, international normalized ratio), wynoszących 13,6 . 
Na podstawie relacji rodziny ustalono, że pacjentka od tygodnia zgłaszała ciemno zabarwione stolce. W dniu przyjęcia nastąpiło poprzedzone zawrotami głowy zasłabnięcie z towarzyszącym upadkiem. W wywiadzie stwierdzono: chorobę wieńcową, stan po zawale serca z uniesieniem odcinka ST (STEMI, ST-elevation myocardial infarction) ściany przednio-bocznej w 2011 roku, stan po pomostowaniu aortalno-wieńcowym (CABG, coronary artery bypass grafting) w 2011 roku, utrwalone migotanie przedsionków rozpoznane w 2006 roku, umiarkowaną niedomykalność mitralną (II klasa niewydolności wg New York Heart Association [NYHA]), wieloletnie nadciśnienie tętnicze, niedoczynność tarczycy, przewlekłe zapalenie błony śluzowej żołądka, chorobę zwyrodnieniowa stawów, otyłość i palenie tytoniu w przeszłości. Dodatkowo występowały okresowe krwawienia z błony śluzowej nosa.

Do tej pory pacjentka stosowała następujące leki: warfarynę, karwedilol, ramipril, spironolakton, atorwastatynę, lewotyroksynę, doraźnie leki przeciwbólowe - ketoprofen i diklofenak.

W badaniach laboratoryjnych potwierdzono zagrażająca życiu niedokrwistość normocytarną 5,0 g/dl oraz INR na poziomie 14,54 . Innych odstępstw od normy nie wykazano. W badaniu przedmiotowym zaobserwowano bladość powłok i świeży uraz głowy bez cech aktywnego zewnętrznego krwawienia, natomiast $w$ badaniu per rectum - czarny, smolisty stolec. W trybie pilnym wykonano tomografię komputerową głowy, nie uwidaczniając istotnych zmian.

Na podstawie wywiadu i obrazu klinicznego wysunięto podejrzenie przedawkowania warfaryny i wtórnego krwawienia z górnego odcinka przewodu pokarmowego. Pacjentkę przekazano na oddział chirurgii w celu wykonania gastrofiberoskopii. Przetoczono 3 jednostki koncentratu krwinek czerwonych (kkcz), podano doustnie $10 \mathrm{mg}$ witaminy $\mathrm{K}$ oraz parenteralnie inhibitor pompy protonowej. W badaniu gastroskopowym stwierdzono zanikowo-nadżerkowe zapalenie błony śluzowej bez czynnego krwawienia oraz przepuklinę rozworu przełykowego. 0 konsultację poproszono również dyżurnego kardiologa. Przedmiotowo zaobserwowano liczne wybroczyny podskórne. W badaniu elektrokardiograficznym stwierdzono migotanie przedsionków z umiarkowaną czynnością komór około 90/min, oś pośrednią i obniżenia odcinka ST w odprowadzeniach I, II, aVL, aVF oraz V2-V6.

Ze względu na konieczność leczenia przeciwkrzepliwego oraz ryzyko ponownego przedawkowania doustnych antagonistów witaminy K (VKA, vitamin K antagonists), po wykluczeniu źródła krwawienia oraz znormalizowaniu parametrów krwi obwodowej i układu krzepnięcia, zaproponowano kontynuację leczenia przeciwkrzepliwego nowymi doustnymi antykoagulantami (NOAC, new oral anticoagulants) - riwaroksabanem w dawce $1 \mathrm{raz} 15 \mathrm{mg} /$ dobę lub dabigatranem w dawce 2 razy $110 \mathrm{mg} /$ dobę doustnie. Po zastosowanym leczeniu uzyskano poprawę stanu kliniczne- go oraz parametrów morfologii krwi obwodowej - stężenie hemoglobiny wynosiło 8,4 g/dl, a INR - 3,4.

W kolejnej dobie nastąpiło załamanie stanu klinicznego z nagłym zatrzymaniem krążenia w mechanizmie asystolii. Podjęte czynności resuscytacyjne były nieskuteczne. Stwierdzono zgon pacjentki. Z powodu nieznanej bezpośredniej przyczyny zatrzymania krążenia przeprowadzono sekcję zwłok. Wynik badania sekcyjnego był następujący: uogólniona choroba nowotworowa o punkcie wyjścia ze szczytu prawego płuca, krwawienie do drzewa oskrzelowego, z wtórnym przedostawaniem się krwi do przewodu pokarmowego, blizna pozawałowa przedniej ściany serca, zmiany guzowate wątroby, miażdżyca uogólniona.

\section{Omówienie}

Doustne leki przeciwkrzepliwe można podzielić na dwie grupy. Pierwsza z nich to VKA. Zadaniem pochodnych 4-hydroksykumaryny - warfaryny i acenokumarolu - jest zapobieganie powstawaniu zredukowanej formy witaminy poprzez hamowanie reduktazy epoksydu witaminy $\mathrm{K}$. Aktywna forma witaminy $\mathrm{K}$ jest niezbędna do utrzymania prawidłowego stężenia czynników II, VII, IX, X, które są podstawowymi ogniwami kaskady krzepnięcia.

O prawidłowym leczeniu przeciwkrzepliwym za pomocą VKA mówi się wtedy, gdy INR pozostaje w przedziale terapeutycznym. Współczynnik ten jest wyliczany na podstawie czasu protrombinowego, który zależy od zewnątrzpochodnego układu krzepnięcia. Prawidłowy INR u osoby nieleczonej powinien wynosić 0,8-1,2. 0 wskaźniku terapeutycznym mówi się wtedy, gdy mieści się on w przedziale 2,0-3,0 (w przypadku migotania przedsionków i VTE) i 2,5-3,5 (w przypadku stosowania u chorych ze sztucznymi zastawkami).

Warfaryna jest metabolizowana w wątrobie z udziałem cytochromów CYP2C9, CYP1A2 i CYP3A do nieczynnych metabolitów wydalanych przez nerki. Jest to przyczyna licznych interakcji lekowych. Dotyczą one powszechnie stosowanych antybiotyków, leków przeciwbólowych, leków antyarytmicznych oraz ziół. Istotna jest również dieta stosowana podczas terapii, w której zasadniczą kwestią jest przyjmowanie stałej ilości witaminy K. Warto podkreślić, że bezwzględnym warunkiem stosowania tej grupy leków jest bardzo dobra współpraca między lekarzem a pacjentem. Niezbędne są okresowe pomiary INR (przynajmniej raz/4 tyg.) i stosowanie się do zaleceń lekarza. Mimo udowodnionej skuteczności w zapobieganiu i leczeniu incydentów zatorowych VKA mają kilka wad: wolny początek działania i długi okres półtrwania, wąski zakres terapeutyczny, nieprzewidywalna odpowiedź pacjentów na leczenie, interakcja z wieloma lekami i pokarmami.

Alternatywą do warfaryny są NOAC - dabigatran, riwaroksaban i apiksaban. Dabigatran jest bezpośrednim, odwracalnym, kompetycyjnym inhibitorem zarówno trombiny wolnej, jak i związanej ze skrzepem. Uniemożliwia on prze- 
mianę fibrynogenu w fibrynę. Natomiast ksabany blokują czynnik X, dezaktywując wewnątrz- i zewnątrzpochodną kaskadę krzepnięcia. Podstawową różnicą w stosunku do VKA jest fakt, że NOAC nie wymagają monitorowania efektu przeciwkrzepliwego. Regularne stosowanie leku wystarcza do uzyskania jego terapeutycznego stężenia.

Przeciwwskazaniem do stosowania NOAC jest migotanie przedsionków na podłożu zastawkowym i ciężka niewydolność nerek. Obniżony współczynnik przesączania kłębuszkowego (GFR, glomerular filtration rate) poniżej $30 \mathrm{ml} / \mathrm{min} / 1,73 \mathrm{~m}^{2}$ powoduje wydłużenie efektu przeciwkrzepliwego. Nie należy włączać nowej generacji leków, gdy GFR wynosi poniżej $30 \mathrm{ml} / \mathrm{min} / 1,73 \mathrm{~m}^{2}$.

W codziennej praktyce lekarz staje przed dylematem, który antykoagulant zastosować u swojego pacjenta. Wybrać sprawdzoną i przystępną cenowo warfarynę czy jednak sięgnąć po lek nowszy, ale znacząco wpływający na domowy fundusz pacjenta? Problem jest jeszcze większy, gdy naszym pacjentem jest osoba powyżej 80. roku życia, przyjmująca dużą liczbę leków, mocno obciążona wywiadem chorobowych i wysokim ryzykiem krwawienia, a jednocześnie coraz mniej zdolna do współpracy.

Podczas podejmowania decyzji można się posiłkować badaniami, w których porównywano skuteczność, profil bezpieczeństwa oraz działania niepożądane doustnych leków przeciwkrzepliwych. Pierwsze z nich to randomizowane badanie RE-LY (Randomized Evaluation of Long-term anticoagulant therapY) [1] dotyczące pacjentów z migotaniem przedsionków i podwyższonym ryzykiem udaru mózgu (przebyty udar lub TIA, frakcja wyrzutowa lewej komory poniżej 40\%, niewydolność serca w co najmniej II klasie NYHA w ciągu ostatnich 6 miesięcy, wiek 75 lat i więcej lat albo 65-74 lat z towarzyszącą cukrzycą, nadciśnieniem tętniczym lub chorobą wieńcową). Badanie to miało umożliwić odpowiedź na pytanie, czy stosowanie dabigatranu w dawce terapeutycznej $(2 \times 150$ mg lub $2 \times$ $\times 110 \mathrm{mg}$ ) jest nie mniej skuteczne od warfaryny i czy jest bezpieczne.

Po 2-letnim okresie obserwowano zmniejszone ryzyko udaru mózgu i zatoru obwodowego dla dawki 2 razy $150 \mathrm{mg} /$ dobę (w stosunku do stowania warfaryny z terapeutycznym INR) i podobne przy dawce 2 razy $110 \mathrm{mg}$. Jednocześnie stwierdzono zmniejszone ryzyko udaru krwotocznego, poważnego krwawienia i zgonu w przypadku stosowania inhibitora trombiny.

Skuteczność i bezpieczeństwo dabigatranu potwierdzono również w długoterminowym badaniu RELY-ABLE (The Long-Term Multicenter Observational Study of Dabigatran Treatment in Patients With Atrial Fibrillation). W badaniu ROCKET AF [2] porównywano z kolei riwaroksaban w dawce $20 \mathrm{mg} /$ dobę i $15 \mathrm{mg} /$ dobę z warfaryną w dawce terapeutycznej. Wykazano nie mniejszą skuteczność inhibitora czynnika X w zapobieganiu udarowi mózgu lub innemu zatorowi w krążeniu dużym oraz obniżenie częstości wystę- powania krwawienia wewnątrzczaszkowego, w narządzie krytycznym i zakończonego zgonem.

Pacjentce przedstawionej w części dotyczącej opisu przypadku klinicznego rozpoznano migotanie przedsionków w 2006 roku. Poza lekami kontrolującymi rytm komór włączono wówczas warfarynę dawkowaną według INR, dążąc do utrzymania wskaźnika w przedziale 2,0-3,0 (docelowo $2,5)$. Analizując historię leczenia przeciwkrzepliwego pacjentki można zauważyć, że przynajmniej $60 \%$ wartości wskaźnika INR mieściło się w zakresie terapeutycznym. Zaobserwowano również okresowe wahania INR sięgające wartości 4.

Ze względu na profil bezpieczeństwa i dogodny sposób stosowania (wg uaktualnienia wytycznych Europejskiego Towarzystwa Kardiologicznego z 2012 r.) u pacjentów z migotaniem przedsionków, u których zaleca się doustne leczenie przeciwkrzepliwe, należy rozważyć zastosowanie nowych doustnych antykoagulantów (ryc. 1) [3].

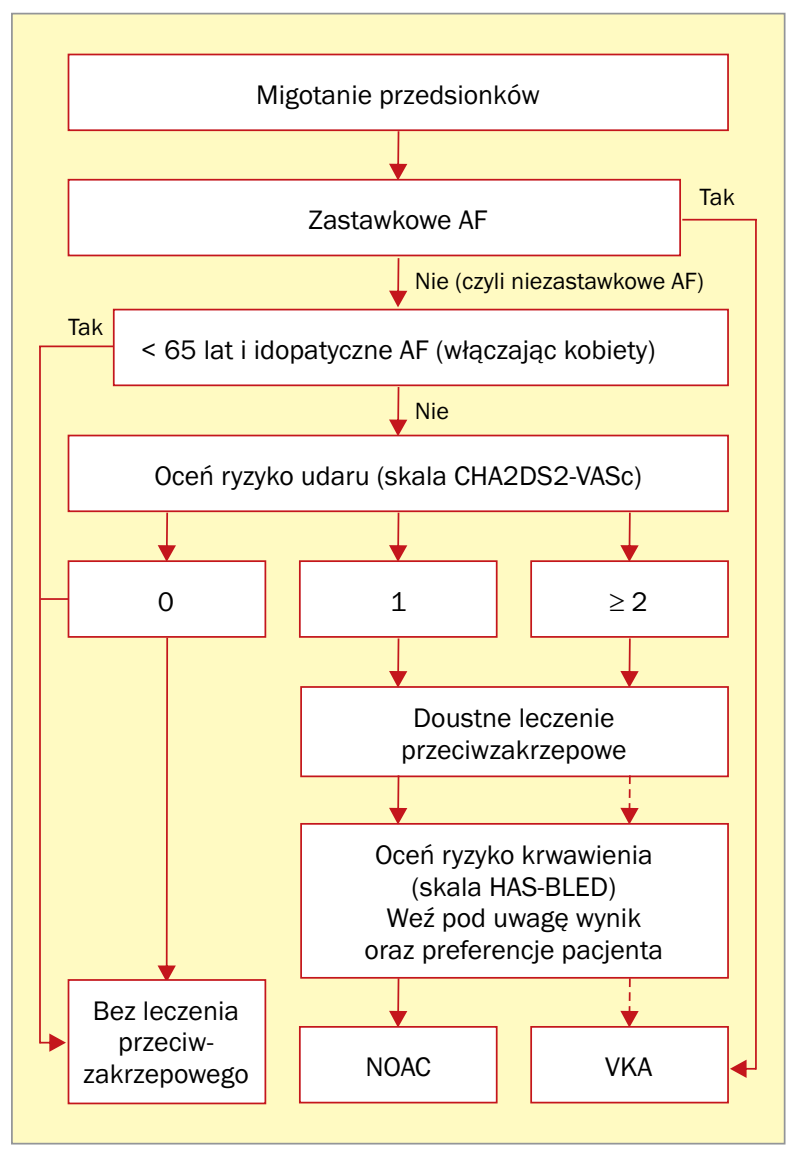

Rycina 1. Wytyczne Europejskiego Towarzystwa Kardiologicznego dotyczące postępowania w migotaniu przedsionków na rok 2012 (na podstawie [3]); linią ciągłą zaznaczono najlepszy wybór, a linią przerywana - wybór alternatywny; AF (atrial fibrillation) - migotanie przedsionków; NOAC (new oral anticoagulants) - nowe doustne antykoagulanty; VKA (vitamin K antagonists) - antagoniści witaminy $\mathrm{K}$ 
Tabela 1. Czynniki ryzyka krwawienia pacjentki w latach 2006 i 2016 na podstawie skali HAS-BLED (źródło [4])

\begin{tabular}{|c|c|c|c|}
\hline & \multirow[t]{2}{*}{ Cecha kliniczna } & \multicolumn{2}{|c|}{ Liczba punktów } \\
\hline & & 2006 r. & 2016 r. \\
\hline H & Nadciśnienie tętnicze & 1 & 1 \\
\hline A & Nieprawidłowa funkcja wątroby i nerek & & \\
\hline $\mathbf{S}$ & Udar mózgu & & \\
\hline B & Krwawienia & & 1 \\
\hline $\mathbf{L}$ & Zmienna wartość INR & & 1 \\
\hline $\mathrm{E}$ & Podeszły wiek (> 65 lat) & & 1 \\
\hline \multirow[t]{2}{*}{ D } & Leki lub alkohol & 1 & 1 \\
\hline & Suma & 2 & 5 \\
\hline
\end{tabular}

U opisanej pacjentki antykoagulant włączono w czasie, kiedy jeszcze NOAC nie były dostępne. Przez kilka następnych lat, mimo dostępności na rynku, ceny nowych leków nie pozwalały zastosować ich u większości pacjentów. Czy zmiany zachodzące na rynku farmaceutycznym obligują nas do ponownego rozpatrzenia leków przyjmowanych przez pacjenta i dostosowania leczenia do obecnych możliwości?

W momencie rozpoznania u chorej migotania przedsionków ryzyko krwawienia według skali HAS-BLED [4] (tab. 1) oceniono na 2 punkty (nadciśnienie tętnicze, przyjmowanie niesteroidowych leków przeciwzapalnych). Natomiast 10 lat później ryzyko wynosiło już 5 punktów (dodatkowo: wiek > 65. rż., labilne wartości INR i krwawienia z błon śluzowych).

Przed włączeniem terapii przeciwkrzepliwej należy określić ryzyko krwawienia. Służy do tego prosta skala HAS-BLED. Jej wynik jednak nie wpływa na decyzję o włączeniu antykoagulantu. W takim razie dlaczego jest tak ważna?

Wysokie ryzyko, tj. wynik nie mniejszy niż 3 w skali HAS-BLED, obliguje do zachowania szczególnej ostrożności w trakcie terapii przeciwkrzepliwej. Konieczne jest wówczas podjęcie trudu wyeliminowania czynników wpływających na ryzyko krwawienia. Mowa tu przede wszystkim o skutecznym leczeniu hipotensyjnym, unikaniu, jeśli to możliwe, leków synergistycznych do leczenia przeciwkrzepliwego oraz bezwzględnej rezygnacji z używek, takich jak alkohol. Należy zwrócić uwagę, że już sama zamiana leczenia VKA na NOAC eliminuje problem labilnych wartości INR.

W trakcie prowadzenia pacjenta stosującego leczenie przeciwkrzepliwe należy zadać sobie pytanie, czy współpraca z nim jest równie dobra jak przy włączeniu terapii, pamiętając jednocześnie, że chory postarzał się o kilka lub kilkanaście lat.

Czy pacjentowi z wysokim ryzykiem krwawienia możemy zaproponować jakieś alternatywne leczenie? W badaniu BAFTA (Birmingham Atrial Fibrillation Treatment of the Aged) [5] sprawdzano przydatność leczenia kwasem acetylosalicynowym w ramach profilaktyki powikłań zakrzepowo-zatorowych w przebiegu migotania przedsionków u pacjentów w podeszłym wieku. Wykazano większą skuteczność warfaryny w zapobieganiu udarów. Co ważne, nie stwierdzono znaczącej różnicy w występowaniu dużych krwawień oraz śmiertelności w obu grupach.

\section{Podsumowanie}

Terapia za pomocą VKA jest trudna i często nieprzewidywalna. Warunkiem bezwzględnym w stosowaniu tej grupy leków jest wyedukowany, zdyscyplinowany i, co również ważne, świadomy zagrażających mu powikłań pacjent. Terapię tę można porównać do balansowania na cienkiej linii - po jednej stronie mamy do czynienia z działaniami niepożądanymi pod postacią zatorów, a po drugiej krwotoków.

Autorzy wytycznych jasno sugerują, że należy rozważyć stosowanie NOAC u każdego, kto wymaga leczenia przeciwkrzepliwego, a także w przypadku trudności z utrzymaniem terapeutycznych wartości INR, działań niepożądanych leczenia za pomocą VKA lub braku możliwości monitorowania współczynnika. W praktyce powinno się systematycznie analizować sytuację kliniczną pacjenta i proponować leczenie najskuteczniejsze, a jednocześnie takie, które ma najbardziej bezpieczny profil działania. Wydaje się, że obecnie takie cechy wykazują NOAC. Zadaniem lekarza jest przedstawienie choremu dostępnych opcji terapeutycznych, a także zagrożeń idących w parze z leczeniem.

Co zrobić, jeśli pacjent nie zgadza się na droższy lek, a jednocześnie nie jest w stanie sprostać trudnej terapii VKA? Trzeba być świadomym, że większy problem to niezastosowanie leczenia, kiedy jest ono wymagane, niż skutki uboczne terapii przeciwkrzepliwej.

Nasz pacjent przez lata się zmienia, dlatego też ulegać zmianie powinno jego leczenie.

W myśl wytycznych Europejskiego Towarzystwa Kardiologicznego „zaleca się, aby dokonywać wyboru leczenia przeciwzakrzepowego, uwzględniając bezwzględne ryzyko 
udaru mózgu/incydentu zakrzepowo-zatorowego i krwawienia oraz względny stosunek korzyści do ryzyka u danego pacjenta " [3].

\section{Konflikt interesów}

Autorzy deklarują brak konfliktu interesów.

\section{Abstract}

The first step of anticoagulant therapy is to make a therapeutic decision based on absolute risk of embolism and bleedings and on patient's benefit-risk ratio. Clinical case has been analyzed of the elderly patient with numerous comorbidities and high risk of bleeding who requires anticoagulant therapy. The objective of this study was to emphasize the variability of bleeding risk during long-term treatment. Based on clinical trials and current guidelines, novel oral anticoagulants can be considered superior to classical therapy with vitamin $\mathrm{K}$ antagonists.

Key words: anticoagulation therapy, anticoagulant, rivaroxaban, dabigatran, overdose, side effect

Folia Cardiologica 2017; 12, 1: 91-95

\section{Piśmiennictwo}

1. Wallentin L, Yusuf S, Ezekowitz MD, et al. RE-LY investigators. Efficacy and safety of dabigatran compared with warfarin at different levels of international normalised ratio control for stroke prevention in atrial fibrillation: an analysis of the RE-LY trial. Lancet. 2010; 376(9745): 975-983, doi: 10.1016/S0140-6736(10)61194-4, indexed in Pubmed: 20801496.

2. Patel MR, Mahaffey KW, Garg J, et al. ROCKET AF Investigators. Rivaroxaban versus warfarin in nonvalvular atrial fibrillation. N Engl J Med. 2011; 365(10): 883-891, doi: 10.1056/NEJMoa1009638, indexed in Pubmed: 21830957.

3. Camm AJ, Lip GYH, De CR, et al. 2012 focused update of the ESC Guidelines for the management of atrial fibrillation: an update of the 2010 ESC Guidelines for the management of atrial fibrillation. Developed with the special contribution of the European Heart Rhythm
Association. Eur Heart J. 2012; 33(21): 2719-2747, doi: 10.1093/ /eurheartj/ehs253, indexed in Pubmed: 22922413.

4. Pisters R, Lane D, Nieuwlaat R, et al. A novel userfriendly score (HAS-BLED) to assess 1-year risk of major bleeding in patients with atrial Ffbrillation. Chest. 2010; 138(5): 1093-1100, doi: 10.1378/ /chest.10-0134, indexed in Pubmed: 20299623.

5. Mant J, Hobbs FD, Fletcher K, et al. BAFTA investigators, Midland Research Practices Network (MidReC). Warfarin versus aspirin for stroke prevention in an elderly community population with atrial fibrillation (the Birmingham Atrial Fibrillation Treatment of the Aged Study, BAFTA): a randomised controlled trial. Lancet. 2007; 370(9586): 493-503, doi: 10.1016/S0140-6736(07)61233-1, indexed in Pubmed: 17693178. 